\title{
Comparison of 7 Days, 14 Days \& 28 Days Cube Crushing Strength of Thirsty Concrete using Different Types of Coarse Aggregate \& Waste Material (Recycled Aggregate) as Coarse Aggregate
}

\author{
Mr. Harishankar Patel ${ }^{1}$ Dr. Lokesh Singh $^{2}$ Mr Pradeep Nirmal $^{3}$ \\ ${ }^{1}$ Research Scholar ${ }^{2}$ Head of Department ${ }^{3}$ Assistant Professor \\ ${ }^{1,2,3}$ Department of Civil Engineering \\ RSR Rungta College of Engineering Technology, Bhilai, India
}

DOI: 10.46335/IJIES.2020.5.7.4

\begin{abstract}
To overcome the problem of water logging due to impermeability of floors and pavement, the pervious concrete is the best solution that increases the better understanding of linkage between microstructure, transport properties and durability will assist in mix proportion and design. There are two major issue while working with Pervious concrete. First is the strength of pervious concrete is very weak due to absence of fine aggregate and other is the high demand for natural construction material. This paper, Represent about the materials, properties, construction \& Design Mix of pervious concrete and provide a details about the limitations and future scope of the usage of pervious concrete in India. The experimental work deals with the effect of different types of coarse aggregate in strength.
\end{abstract}

A total numbers of 45 specimens were cast with $20 \mathrm{~mm}$ size \& other 45 specimen cast with $12 \mathrm{~mm}$ size aggregate of angular, flaky, rounded, broken marbles and recycled aggregate cured and tested for compressive strength. The specimens were cast without adding any fine aggregate with the mix proportion 1: 4.38 (cement: aggregate) and by adding 10\% fine aggregate with the mix proportion 1:0.438:3.95 (cement: sand :aggregate). This research is total of two different mixes of various shape and materials were used such as without and with fine aggregates, two different coarse aggregates, of size $12 \mathrm{~mm}$ and 20mm. The experiment has been done in this project has considered 7 days, 14days and 28 days compressive strength of pervious concrete. The mix M2 with river sand as Normal River sand and crusher stone sand and $12 \mathrm{~mm}$ coarse aggregate has shown superior performance in terms of higher compressive strength than mixM1.

Keywords- Angular, Flaky, Rounded, Broken Marble and Recycled Aggregate, Pervious Concrete, Sand.

\section{I- INTRODUCTION}

$\mathbf{E}$ $\mathrm{A}_{\text {very city has its unique challenges. In the cities }}$ which are situated near the sea like Chennai, Kolkata and Mumbai if there are heavy rainfalls happens during high tide, then the tide causes the water to wash back into the city, and it is not absorbed by the surface that leading to water logging. A lack of state-of-the-art rain forecasting system could have been a factor in water logging earlier but India recently updated its weather tech and the blame for water logging now squarely lies 
on the unpreparedness of the state municipal corporations.

Adding to manmade problems are natural reasons for this problem getting worse each year. As the health of countries worsens, the health of its states \& cities worsen too. The absorbing of Water such as wastelands, saltpans, wetlands and mangroves of our country are shrinking due to reestablishments of land uses for development - this leaves more and more storm water to be dealt with by civic authorities who are already burdened with a multitude of problems.

Pervious concrete is known as the special type of concrete that have high voids which increases it's permeability applied for concrete work \& flatwork applications that permits water from weather action like precipitation, raining and other sources to travel through it, which minimizing the runoff from the effected site and can recharging ground water levels. Typically thirsty concrete has no fine aggregate or has little fine aggregate and has just appropriate cementious paste to overcoat the coarse aggregate particles while conserving the interrelativity of the pores.

Background History of Pervious Concrete:- Pervious concrete was first applied in 1800 in Europe as pavement material for surface covering and structure of load bearing. The initial use of pervious concrete was made in the Britain in near to 1850 with the construction of two houses of residential and a seawall. The pervious concrete is applied initially in 1852 (Ghafoori and Dutta). Although not a new technology, pervious concrete is achieving renewed interest in the America, partly cause of FCWL(Federal Clean Water Legislation). The (USEPA)Environmental Protection Agency's Phase II requires the Final Rule to operators of all municipalities in urban areas to develop, execute, and impose a program to minimize pollution particles in post-construction runoff from redevelopment and new growth projects that outcome in disturbance of land of greater than or equal to 1 acre.

Pervious concrete is a highly porous type of concrete which is light in weight and it is obtained by reducing, replacing or withdrawing the fine aggregate from the conventional concrete. The ingrained properties of the thirsty concrete is low cost due to less cement content, low bulk density, low conductivity of temperature and drying shrinkage, less segregation and high porous movement of water. Due to the availability of large voids, this concrete is applied as a permeable material. Pervious concrete does not represent the sufficient strength of compression due to pervious material with conventional shape and size though it need to prevent storm water runoff from initiating flood and downstream abrasion. Pervious concrete is basically used in parking areas wherethe traffic is light, pedestrian walkways, foot-path, and greenhouses. Pervious concrete is an improved implementation for sustainable construction of structure.

This experimental work is carried out to enhance the strength of compression of thirsty concrete with alternate shape and size of aggregate with little percentage of fine aggregate say $10 \%$.

\section{II- Material Used}

The Portland cement is used as binding material, Tap water, Crushed quarry rocks and river sands as other ingredients. Crushed coconut shells are used as replacement for coarse aggregates, their description is as follows

A. Cement

Powdery form and manufactured by calcareous material like clay and lime, siliceous and argillaceous material, act as the binding material when mixed with water.

Test were conducted on cement and the results are presented in Table 1.

B. Fine aggregate

Sand which is accumulated of granular material or particles in rounded form was used as fine aggregate in MIX2 number of test were conducted to determine the properties of natural sand shown in Table 2

C. Coarse aggregates

The aggregate of various size \& shapes were including recycled coarse aggregates were used in as two categories mixed of $12 \mathrm{~mm} \&$ upto 20 $\mathrm{mm}$ size nominal aggregate. Indian Standard was followed to while testing materials. The test results are presented in Table 3. 
International Journal of Innovations in Engineering and Science, Vol 5, No.7, 2020 $w w w . i j i e s . n e t$

Table.1 Properties of cement

\begin{tabular}{|l|l|l|}
\hline Name of the Test & $\begin{array}{l}\text { Experimental } \\
\text { Results }\end{array}$ & $\begin{array}{l}\text { Std values as per IS 12269 -1989 (R A } \\
\text { 2008) }\end{array}$ \\
\hline Fineness Test & $6 \%$ & Shall not be more than 10\% \\
\hline Consistency & $32.20 \%$ & Not Specified \\
\hline Initial Setting Time & 35 minutes & Shall not be less than 30 minutes \\
\hline Final Setting Time & 245 minutes & Shall not be more than 600 minutes \\
\hline Sp. Gravity of Cement & 3.15 & Not Specified \\
\hline
\end{tabular}

Table.2 Properties of sand

\begin{tabular}{|l|l|l|}
\hline Name of the Test & $\begin{array}{l}\text { Experimen } \\
\text { tal Results }\end{array}$ & $\begin{array}{l}\text { Std values as per 383 } \\
-\mathbf{1 9 7 0}(\mathbf{R} \text { A 2007) }\end{array}$ \\
\hline Sp. Gravity of sand & 2.65 & Not Specified \\
\hline Water Absorption & $3 \%$ & Not Specified \\
\hline
\end{tabular}

Table.3 Properties of coarse aggregate

\begin{tabular}{|l|l|l|l|}
\hline \multirow{4}{*}{ Test Conducted } & \multicolumn{2}{|l|}{ Result } & \multirow{2}{*}{ Std values as per IS 383-1970 (RA 2007) } \\
\cline { 2 - 3 } & \multicolumn{2}{|l|}{ Aggregate Size } & \\
\cline { 2 - 3 } & $20 \mathrm{~mm}$ & \multicolumn{1}{|l}{$12 \mathrm{~mm}$} & \\
\hline Sp. Gravity & 2.7 & $\mathbf{2 . 6 5}$ & Not Specified \\
\hline Water Absorption & $\mathbf{0 . 8 4 \%}$ & $\mathbf{2 . 5 0 \%}$ & Not Specified \\
\hline Crushing Value & 17 & 19 & Shall not exceed 45\% \\
\hline Flakiness Index & 36.2 & 29 & Shall not exceed 35\%-40\% as per SP23 \\
\hline Flakiness Index & $\mathbf{4 6 . 2}$ & 40 & Shall not exceed 45\%-50\% as per SP23 \\
\hline
\end{tabular}

\section{III-METHODOLOGY}

The raw materials used in this experimentation were locally available and these included most common binding agent as OPC, fine aggregates is sand procured locally and crushed shale stones and coconut sh ell. Tap water is used for mixing and curing as it is easily available. The material used for coarse aggregate will be having minimum particle size of $4.75 \mathrm{~mm}$. Do a thorough cleaning to remove clay particles. The Methodology used in this study is depicted below:

\subsection{Selection of materials:}

1. Cement

2. Fine aggregate

3. Coarse aggregate(Stone quarry)

4. Coconut shell

3.2 Tests on materials:

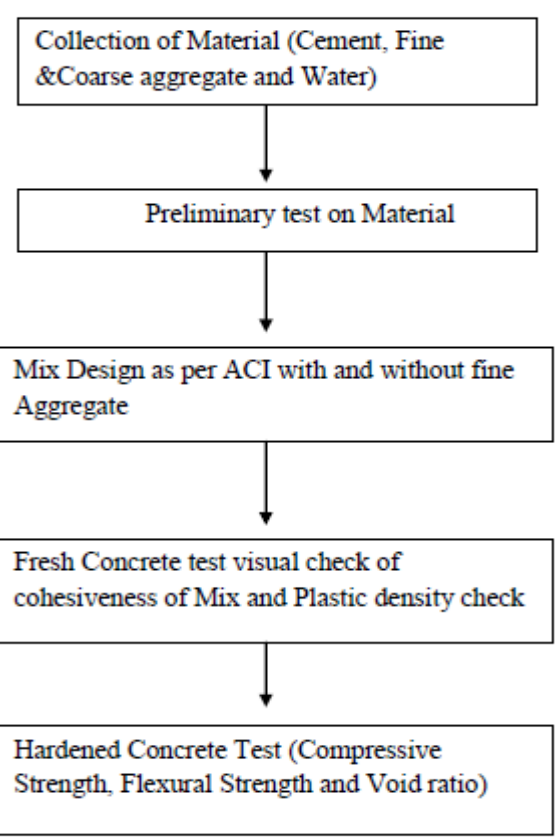

Chart 3.1- Flow chart of methodology 
Table 4: Tests on materials

\begin{tabular}{|c|c|c|c|}
\hline S. No & Material & Test & Apparatus \\
\hline \multirow[t]{4}{*}{1.} & \multirow[t]{4}{*}{ Cement } & Specific Gravity & Le-Chatelier flask \\
\hline & & Standard Consistency & Vicat's apparatus \\
\hline & & Initial and Final Setting Time & Vicat's apparatus \\
\hline & & Fineness Test & Sieve shaker \\
\hline \multirow[t]{2}{*}{2} & \multirow[t]{2}{*}{ Fine aggregate } & Sieve Analysis of fine aggregate & Sieve shaker \\
\hline & & Water Absorption & \\
\hline \multirow[t]{7}{*}{3} & \multirow[t]{7}{*}{ Coarse Aggregate } & Specific gravity & Wire Basket \\
\hline & & Water Absorption & \\
\hline & & Aggregate impact test & Impact testing machine \\
\hline & & Aggregate crushing value & $\begin{array}{l}\text { Compression testing } \\
\text { machine }\end{array}$ \\
\hline & & Flaky ness index & Flaky ness gauge \\
\hline & & Elongation index & Elongation gauge \\
\hline & & Abrasion Value & Los angelus \\
\hline
\end{tabular}

\subsection{Mix Proportions:}

A total numbers of 45 specimens were cast with 20 $\mathrm{mm}$ size \& other 45 specimen cast with $12 \mathrm{~mm}$ size aggregate of angular, flaky, rounded, broken marbles and recycled aggregate cured and tested for compressive strength. The specimens were cast without adding any fine aggregate with the mix proportion 1: 4.38 (cement: aggregate) and by adding $10 \%$ fine aggregate with the mix proportion 1:0.438:3.95 (cement: sand :aggregate). This research is total of two different mixes of various shape and materials were used such as without and with fine aggregates, two different coarse aggregates, of size $12 \mathrm{~mm}$ and $20 \mathrm{~mm}$. The experiment has been done in this project has considered 7 days, 14days and 28 days compressive strength of pervious concrete.

\section{IV- RESULTS}

For the above mentioned mixes \& samples with different shape and origin of coarse aggregate including broken marble \& recycled aggregate as replacement for the coarse aggregate compressive strength test was performed following tables as well as chart represent the findings:-
Table 5.1 Average Compressive strength of concrete for different shape \& types of aggregate of MIX-1

\begin{tabular}{|c|c|c|c|c|}
\hline \multirow{2}{*}{$\begin{array}{c}\text { S.N } \\
\mathbf{0}\end{array}$} & $\begin{array}{c}\text { Aggregate } \\
\text { type }\end{array}$ & \multicolumn{2}{|c|}{$\begin{array}{c}\text { Compressive Strength } \\
\text { (MPa) Mix-1 }\end{array}$} & \\
\cline { 3 - 5 } & & $\mathbf{7 ~ d a y s}$ & $\mathbf{1 4}$ days & 28days \\
\hline 1 & Angular & 5.515 & 7.54 & 8.886 \\
\hline 2 & Rounded & 3.217 & 4.085 & 4.861 \\
\hline 3 & Flaky & 4.374 & 6.312 & 7.130 \\
\hline 4 & $\begin{array}{l}\text { Broken } \\
\text { marble }\end{array}$ & 1.845 & 2.547 & 2.826 \\
\hline 5 & $\begin{array}{c}\text { Recycled } \\
\text { Aggregate }\end{array}$ & 4.882 & 6.302 & 7.385 \\
\hline
\end{tabular}

Table 5.2 Average Compressive strength of concrete for different shape \& types of aggregate of MIX-2

\begin{tabular}{|c|c|c|c|c|}
\hline \multirow{2}{*}{$\begin{array}{c}\text { S.N } \\
\text { o }\end{array}$} & \multirow{2}{*}{$\begin{array}{c}\text { Aggregat } \\
\text { e type }\end{array}$} & \multicolumn{2}{|c|}{$\begin{array}{c}\text { Compressive Strength } \\
\text { (MPa) Mix-2 }\end{array}$} & \\
\cline { 3 - 5 } & & $\mathbf{7}$ days & $\mathbf{1 4}$ days & 28days \\
\hline 1 & Angular & 7.209 & 10.564 & 12.14 \\
\hline 2 & Rounded & 4.122 & 5.288 & 5.748 \\
\hline 3 & Flaky & 5.38 & 6.57 & 8.48 \\
\hline 4 & Broker & 2.628 & 3.982 & 4.464 \\
\hline 5 & $\begin{array}{c}\text { Recycled } \\
\text { Aggregate }\end{array}$ & 5.90 & 9.081 & 9.702 \\
\hline
\end{tabular}




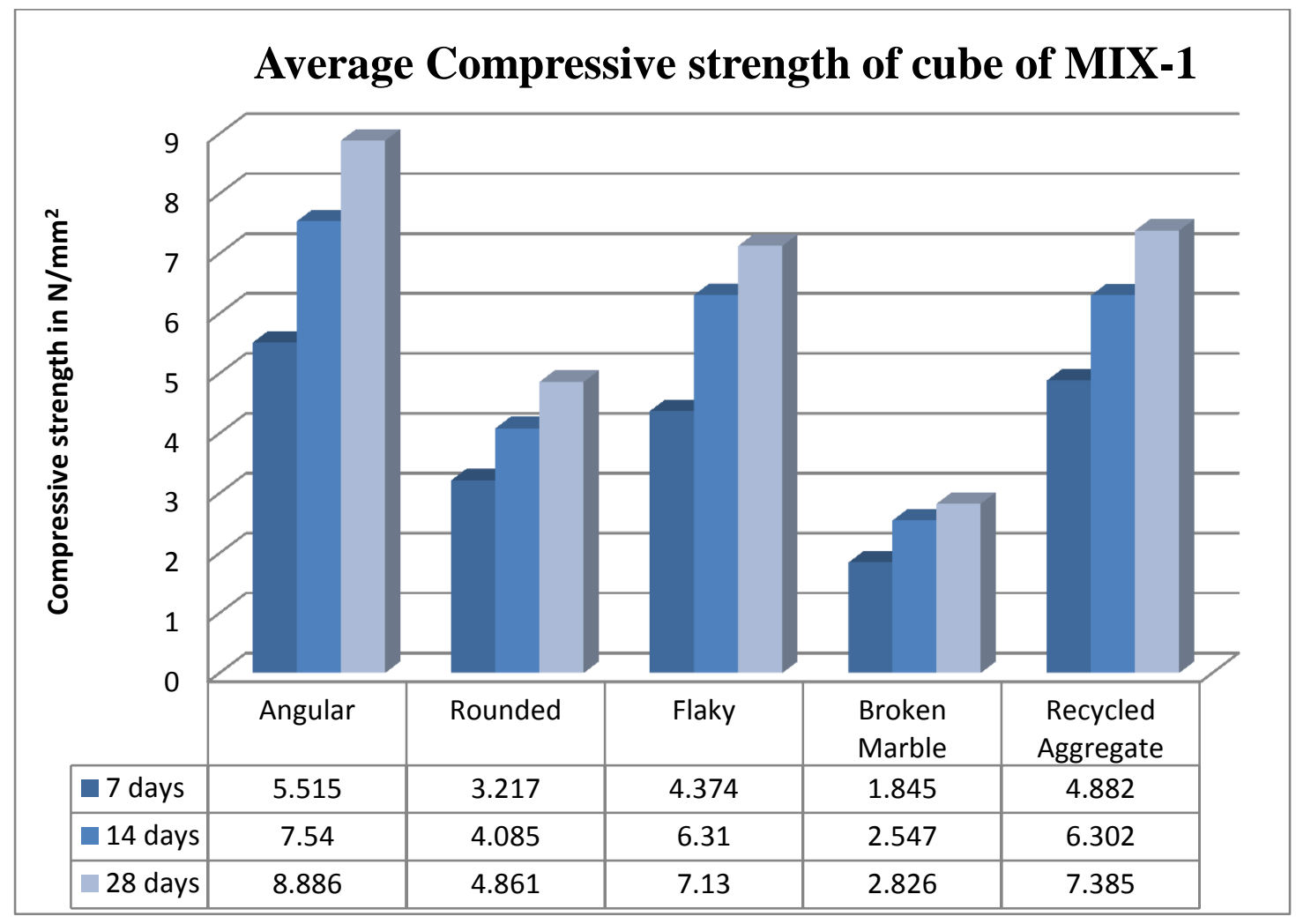

Chart-5.2 Average Compressive strength of concrete cube

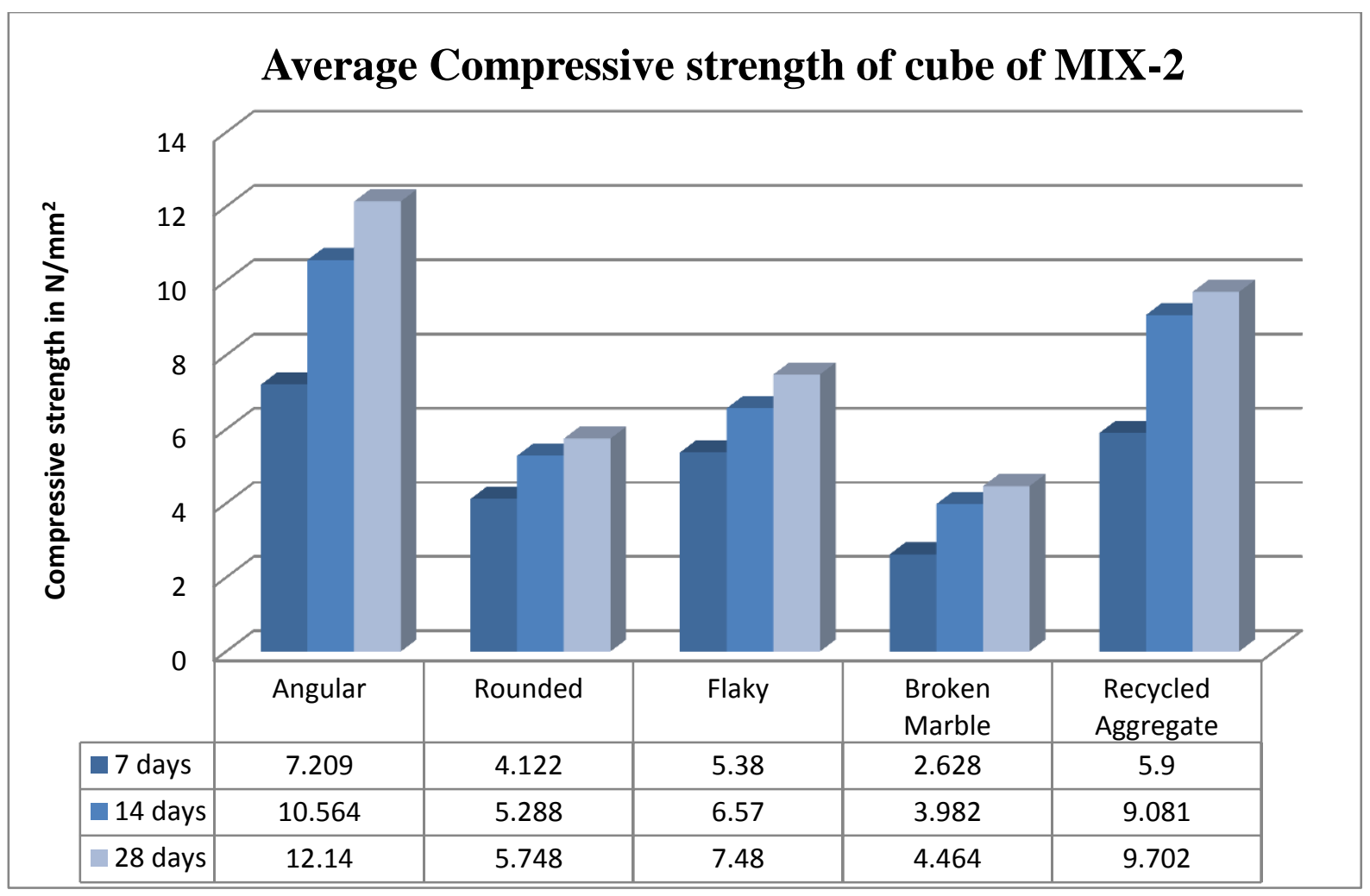




\section{V- CONCLUSIONS}

The following are the conclusions and recommendations made by this study. According to the experimental results, it has been observed that, From the experiments conducted on the Curing of concrete, developed in the concrete laboratory of RSR RCET, Among the all types of aggregate used the following conclusions have been made.

- The compressive strengths of cubes made up of angular and recycled aggregate are considerable.

- The compressive strength of cubes remarkably increases by adding fine aggregate for the preparation of pervious concrete.

- The compressive strength and resistance property to wearing of concrete made by recycled aggregate is near to the pervious concrete made by angular aggregate

- The compressive strength of pervious concrete with $12 \mathrm{~mm}$ size aggregate are remarkably more than pervious concrete of $20 \mathrm{~mm}$ size aggregate.

- The Mix-2 gives approximately $30.91 \%$ more compressive strength as compare to Mix-1.

- The replacement of aggregate by recycled aggregate rather than broken marble is more effective. Hence recycled aggregate can be used to make the thirsty concrete.

- Flaky aggregates which are generally exceptional are waste material also perform an excellent alternate of conventional aggregate.

\section{REFERENCE}

[1] Jing Yang, Guoliang Jiang. - Experimental study on properties of pervious concrete pavement materials Cement and Concrete Research 33 (2003) 381-386 ISSN 0008-8846.

[2] Kevern, J.T. Mix Design Determination for Freeze-thaw Resistant Portland Cement Pervious Concrete, Master's Thesis, Ames, IA: Iowa State University, 2006.

[3] Kevern, J. T., Wang, K., Suleiman, M. T., and Schaefer, V. R. "Pervious Concrete Construction: Methods and Quality Control." CD-ROM. Proceedings of the 2006 NRMCA Concrete Technology Forum - Focus on Pervious Concrete, Nashville, TN, 2006.

[4] Schaefer, V.R., Wang, K., Sulieman, M.T., and Kevern, J. Mix Design Development for Pervious Concrete in
Cold Weather Climates. A Report from the National Concrete Pavement Technology Center (CP Tech Center), Ames, IA: Iowa State University, 2006.

[5] P.C.Bala murugan, R.Avinash. - Experimental Probe on Thirsty Concrete Using Recycled Aggregate (2019) ISSN: 2349-6002

[6] Prof. Shilpi S. Bhuinyan, Shreyance Luniya. -An Experimental Study on Strength and Properties of Thirsty Concrete (2019) ISSN: 2349-6002

[7] S. Rajesh Kumar. - Characteristic Study on Pervious Concrete (2015) ISSN:0976 - 6308

[8] Vima Velayudhan Ithikkat and Dipu V S, "Analytical Studies On Concrete Filled Steel Tubes" International Journal of Civil Engineering \& Technology (IJCIET), Volume 5, Issue 12, 2014, pp. 99 - 106, ISSN Print: 0976 - 6308, ISSN Online: 0976 - 6316.

[9] IS 456-2000, "Indian Code of Practice for Plain and Reinforced concrete" Bureau of Indian Standards, Fourth revision, New Delhi

[10] IS 516: 1959 methods of tests for strength of concrete (RA1991).

[11] IS: 383-1970, "Specification for coarse and fine aggregates from Natural sources for concrete", Bureau of Indian Standards, ninth reprint, New Delhi.

[12] IS: 383 (1970), 'Code of practice for the Specification for coarse and fine aggregate from natural source for concrete', Bureau of Indian Standards, New Delhi.

[13] IS: 456 (2000), 'Code of practice for Plain and Reinforcement concrete', Bureau of Indian Standards, New Delhi.

[14] IS: 10262 (2009). "Concrete Mix Proportioning Guidelines”, Bureau of Indian Standards, New Delhi. 